\title{
Study of the Electrochemical Behavior of Melatonin on Different Electrodes in Aqueous Solution
}

\author{
G. I. Mohammed ${ }^{1}$, A.L.Saber ${ }^{1,2, *}$ \\ ${ }^{1}$ Department of Chemistry, Faculty of Applied Science, Umm Al-Qura University, P.O. Box 16722, \\ Makkah 21955, Saudi Arabia \\ ${ }^{2}$ Department of Chemistry, Faculty of Science, University of Zagazig, Zagazig, Egypt \\ *E-mail: alshefny@yahoo.com
}

doi: $10.20964 / 2020.06 .90$

Received: 28 September 2019 / Accepted: 1 April 2020 / Published: 10 May 2020

The electrochemical investigation of melatonin was researched utilizing cyclic, linear sweep voltammetry at a glassy carbon $(\mathrm{GC})$, gold $(\mathrm{Au})$ and platinum $(\mathrm{Pt})$ terminals. The aim of this work was to study the behavior of melatonin at different electrodes. The cyclic voltammetry (CVs) of melatonin $\left(1.0 \times 10^{-4} \mathrm{~mol} \mathrm{~L}^{-1}\right)$ were critically investigated at various sweep rate $(10-1000 \mathrm{mV} / \mathrm{s})$ at $\mathrm{GCE}, \mathrm{AuE}$ and $\mathrm{PtE}$ in B-R buffer solution of $\mathrm{pH}$ 7. The repeatability, reproducibility and selectivity of all electrodes were investigated. These electrodes were successfully applied for the analysis of melatonin pharmaceutical dosage forms without electroactive interferences from the tablet excipients

Keywords: Cyclic voltammetry, Glassy carbon electrode, Gold electrode, Melatonin, Platinum

\section{FULL TEXT}

(C) 2020 The Authors. Published by ESG (www.electrochemsci.org). This article is an open access article distributed under the terms and conditions of the Creative Commons Attribution license (http://creativecommons.org/licenses/by/4.0/). 